\title{
Debt-driven growth? Wealth, distribution and demand in OECD countries
}

\author{
Engelbert Stockhammer and Rafael Wildauer, \\ Kingston University, KT1 2EE
}

Version 2.00, June 2015

\begin{abstract}
The paper investigates the effects of changes in the distribution of income and in wealth on aggregate demand and its components. We extend the Bhaduri and Marglin (1990) model to include personal income inequality as well as asset prices and debt. This allows for an evaluation of the wage or profit-led nature of demand regimes, of the expenditure cascade argument (Frank et al. 2014) and several hypotheses regarding the effects of wealth and debt. Our estimates are based on a panel of 18 OECD countries covering the period 1980-2013. For the full panel the average demand regime is found to be wage led. We fail to find effects of personal inequality, but do find strong effects of debt and property prices which have been the main drivers of aggregate demand in the decade prior to the 2007 crisis.
\end{abstract}

Keywords: post-Keynesian economics, wage-led growth, Bhaduri-Marglin model, demand regimes, wealth effect, Veblen effect, expenditure cascade, aggregate demand

JEL codes: E11, E12, E21,

Acknowledgements: This paper is part of the research project 'Rising inequality as a structural cause of the present financial and economic crisis' with financial support by the Institute for New Economic Thinking. An earlier version of this paper was presented at the workshop Inequality, debt and demand, Kingston University, Sept 2014, and has benefited from discussion there. We are grateful to Robert Blecker, Jakob Kapeller, Yun Kim, Hiroshi Nishi, Soon Ryoo and two anonymous referees for helpful comments. The usual disclaimers apply. 


\section{Debt driven growth? Wealth, distribution and demand in OECD countries}

\section{Introduction}

The effects of the changes in income distribution on aggregate demand and the role of debt and financial assets are two intensely debated issues in modern heterodox macroeconomics. This development reflects important changes in contemporary capitalism. Since 1980 dramatic shifts in the distribution of income as well as in the valuation of assets have occurred. Figure 1 shows the evolution of the wage and top income shares, real house prices and household debt for five major OECD countries. Wage shares have been falling in all countries. Top incomes as well as property prices and household debt have increased in most but not all countries. Notably Germany and Japan did not experience a property price boom in the decade prior to 2008. While there is agreement on the trends and their importance, there is disagreement in heterodox macroeconomics on their relative theoretical and practical importance.

[Figure 1]

As regards the role of income distribution there have been two important debates. First, on changes in the functional distribution of income, Kaleckians have argued that an increase in the wage share will increase aggregate demand (called a wage-led demand regime) because the propensities to consume out of wages is higher than that out of capital incomes (Kalecki 1954). On the contrary, Marxists (Goodwin 1967) argue that higher profits translate into higher investment (called a profitled demand regime). Bhaduri and Marglin (1990) presented a unifying framework, which allows for both wage-led and profit-led regimes that has become a widely used tool within post-Keynesian economics and has inspired a rich empirical literature (Bowles and Boyer 1995; Stockhammer and Onaran 2004; Naastepad and Storm 2007; Hein and Vogel 2008; Stockhammer and Stehrer 2011; Onaran and Galanis 2012). Most of this literature focuses on the effects of changes in the functional income distribution, but pays little attention to other factors. The second debate about income distribution focused on the sharp rise in top incomes (Atkinson et al. 2011). The standard Kaleckian hypothesis is that rising inequality will lead to lower consumption expenditures as the rich will have a lower consumption propensity than the poor. However, Frank et al. (2014) argue that people will 
emulate consumption patterns of richer peers in an attempt to climb up the social ladder. Rising personal income inequality will thus lead to expenditure cascades and increase consumption. ${ }^{1}$

Post-Keynesian (PK) macroeconomics has long recognised the importance of finance in general and asset prices and debt specifically. Minsky (1995) regarded debt cycles as the driver of economic fluctuations. Recently there have been several attempts to formalise his model (Charles 2008; Fazzari et al. 2008; Keen 1995; Ryoo 2013). ${ }^{2}$ There is also a surge in interest in stock-flow consistent (SFC) models (Godley and Lavoie 2007), which highlight the impact of stock variables such as debt and net wealth on macroeconomic aggregates. We note two shortcomings in this debate. First, while there is an agreement on the key role of debt and wealth, there is no agreed-upon model. In Minsky's analysis business debt is central. This clearly does not fit the recent experience of rising household debt and a consumption boom. In contrast the stock-flow consistent modelling (SFC) literature typically highlights household debt and it often allows for different stock and flow effects of debt or asset prices. Palley (1994), Dutt (2006) and Hein (2012a) include household debt in Kaleckian models and Isaac and Kim (2013) is one of the few paper that explicitly model business as well as household debt simultaneously. Second, the debate has so far motivated more theoretical than empirical work (Zezza 2009 is one of the few exceptions). Overall, post-Keynesian macroeconomics here lags behind the mainstream literature, which has built a substantial body of empirical research on wealth effects and consumption, which is ironic, given that most mainstream macro models have given little role to debt. Onaran et al. (2011) on the USA is one of the few post-Keynesian studies analysing the effects of functional income distribution and household wealth and debt, but it does not investigate the role of personal income distribution and, importantly, only a single country is analysed.

The aim of the paper is to analyse the effects of changes in functional and personal income distribution as well as changes of household and business wealth and debt on aggregate demand and its components. We are interested in the sign of the effects, which will allow us to evaluate whether demand is wage-led or profit-led and whether expenditure cascades or 'the rich save more' effects dominate. But we also want to analyse the growth contribution of these effects, in order to determine to what extent the characterisation of growth as 'debt-driven' or 'finance-led' (Stockhammer 2012; Hein 2012b) is a useful description.

The paper extends a Bhaduri-Marglin model for measures of personal income inequality as well as measures of property and financial wealth and private debt. We estimate it based on a panel of 18

\footnotetext{
${ }^{1}$ We use the terms expenditure cascades and Veblen effects synonymously.

${ }^{2}$ Another example for a model of endogenous financial fragility cycles is Bhaduri (2011), however in that version debt peaks at the lower turning point of the business cycle, which is not compatible with the Minsky's argument.
} 
OECD countries covering the period 1980 to 2013. Our contribution is threefold: First, we provide a neo-Kaleckian framework to analyse the effects of distribution and wealth on aggregate demand and its components. This allows us to assess different hypotheses on the effects of wealth and debt variables. Second, we provide an empirical assessment of the relative growth contributions of these effects for different country groups. Third, we estimate our model by means of panel analysis whereas most of the relevant literature relies on time series evidence for individual countries.

The panel approach does impose the restriction that parameters are identical across countries, which clearly will only hold as an approximation. Panel analysis comes with costs as well as benefits. Its main advantage is that it allows for including a rich set of country experiences, i.e. more variation in the variables. In particular we include many European countries, whereas most of the research on wealth effects focuses on Anglophone ${ }^{3}$ countries. Given that data for household and business debt is only available since 1980 for the majority of countries studied and that top income data is only available annually, our research question can only be explored by panel analysis. However, we will provide some evidence that the pooling assumption is a reasonable approximation and that heterogeneous outcomes across the countries are driven primarily by differences in the time paths of the explanatory variables rather than by differences in parameters across countries.

The remainder of the paper is organized as follows: Section 2 presents our theoretical framework. Section 3 reviews the existing empirical literature dealing with the Bhaduri-Marglin framework and the empirical literature estimating wealth and debt effects. Section 4 discusses the data set and the econometric issues arising when applying panel data methods in a macroeconomic context. Section 5 presents the results and a final section concludes.

\section{The theoretical framework}

The starting point for our investigation is the Bhaduri and Marglin (1990) model that has become a standard reference point in modern post-Keynesian economics. We extend the model to include expenditure cascades and wealth and debt effects in both investment and consumption. Real aggregate demand $(Y)$ consists of consumption spending $(C)$, investment expenditures $(I)$, net exports $(N X)$ and government spending $(G)$. We abstract from government and thus write aggregate demand as:

$$
A D=C+I+N X
$$

\section{Consumption is}

\footnotetext{
${ }^{3}$ We prefer the term 'Anglophone countries' to the more frequently used term 'Anglo-Saxon countries' as more precise. The Angles and Saxon were Germanic tribes of late antiquity that have little relation to presentday English speaking countries.
} 


$$
C=C(Y, W S, Q, W H, W F, D H, \Delta D H)
$$

With $C_{Y}, C_{W S}, C_{W H}, C_{W F}, C_{\Delta D H}>0, C_{D H}<0, C_{Q}=$ ?

where $Y, W S, Q, W H, W F$, and $D H$ are income, the wage share, personal income inequality, housing wealth, financial wealth and household debt, respectively. We expect $Y$ and $W S$ to have a positive effect. In the latter case due to the fact that the marginal propensity to consume (MPC) out of wage income is likely to be higher than that out of capital income. The personal distribution of income is relevant for two reasons. First, the marginal as well as average propensities to consume vary across income groups. The standard assumption here is that the poor have a higher MPC, which would imply a negative effect of inequality on consumption $\left(\frac{\partial C}{\partial Q}<0\right)$. Second, if households care about consumption and income relative to their peers, an increase in inequality has a positive effect on consumption $\left(\frac{\partial C}{\partial Q}>0\right)$. Following the work of Duesenberry (1949), Frank (1985) and Frank et al. (2014) developed the theory of consumption cascades, which can occur when people have upwardlooking consumption norms, i.e. if they try to keep up with those above them in the income distribution. Several authors have incorporated these assumptions in macroeconomic models (Kapeller and Schütz 2014; Belabed et al. 2013).

The role of household wealth and household debt for aggregate demand formation has recently gained prominence, however there are several competing hypotheses, which are summarised in Table 1. Keynesians have long highlighted the importance of financial factors, but consumption has traditionally not featured prominently in these contexts. Early contributions highlighted that changes in the liquidity preference could cause financial crises (Keynes 1973; Davidson 1972). The main transmission mechanism for this was interest rates. In PK models household debt has a dual influence on consumption since it provides a source of finance, thus having a positive impact on consumption but also leads to servicing costs which depress consumption if the MPC out of interest income is low (Dutt 2006; Nishi 2012a; Hein 2012a). In our context this implies the hypothesis of $\frac{\partial C}{\partial D H}<0$ because higher debt levels also lead to higher interest payments and thus decrease disposable income and thus consumption. On the other hand $\frac{\partial C}{\partial \Delta D H}>0$ since taking on additional debt initially increases disposable income and the ability to finance consumption expenditures. Therefore the overall effect is not a priory clear. However, a shortcoming of these models is that they do not explicitly assign a role to asset prices (or net wealth) and especially housing. This is problematic in particular because the most important reason for households to go into debt is not consumption related, but asset transaction related, namely the acquisition of homes. On the other hand real estate is an important collateral and equity withdrawals provide a convenient excess to consumer debt. The Minskyian stream within post-Keynesian economics has long emphasised the 
role of asset prices in borrowing (and lending). In these models (Ryoo 2013), optimistic investors will drive up asset prices during boom phases, lowering corporate financing costs and thus encouraging businesses to take on more debt. However, Minsky's original writings analysed businesses and their debt rather than households and mortgage debt. Extending his argument to households, we would expect a strong effect of housing wealth, which underwrites household debt and we would expect autonomous movements in housing wealth to drive both, debt and consumption, $\frac{\partial C}{\partial W H}>0 .{ }^{4}$

In mainstream consumption theory households maximise utility over the life-cycle. Thus net wealth, which is assets minus liabilities $(N W=W H+W F-D H)$, plays a key role. If net wealth is the variable to affect consumption, this implies $\frac{\partial C}{\partial(W H+W F)}=-\frac{\partial C}{\partial D H}$. However, it is not straight forward that measured net wealth is the relevant variable. Buiter (2010) argues that housing wealth does not constitute wealth since rising prices only make consumers who are long in housing better off, whereas those who rent are worse off. He shows that in a representative agent model the net effect is zero, i.e. $\frac{\partial C}{\partial W H}=0$. New Keynesian modifications of the neoclassical model highlight the possibility of credit rationing (Muellbauer 2007). In these models housing wealth can relax credit constraints because it serves as collateral $\left(\frac{\partial C}{\partial W H}>0\right)$ and we would expect $\frac{\partial C}{\partial W H}>\frac{\partial C}{\partial W F}$ because housing wealth is more likely to be accepted as collateral than financial wealth.

[Table 1]

Investment is

$$
\begin{gathered}
I=I(Y, W S, i, Q, W H, W F, D H, D B) \\
\text { With } I_{\gamma}, I_{W F}, I_{\triangle D B}, I_{\triangle D H}>0, I_{i}, I_{D B}, I_{D H}<0, I_{W S}, I_{Q} I_{W H}=?
\end{gathered}
$$

where $i$ and $D B$ are the long term real interest rate and business debt respectively. Aggregate demand and long-term real interest rates are standard in investment functions. The wage share may indicate future profitability and retained earnings are an important source of funding. Stock markets represent funding conditions for firms and are considered a leading business cycle indicator. We expect a positive effect. Total investment consists of business investment and residential investment. We regard residential investment as determined by a similar set of variables as consumption expenditures, i.e. our investment function will also depend on the wage share, income inequality, housing and financial wealth, and household debt. Three remarks are in order. First, while business

\footnotetext{
${ }^{4}$ This means that in our context the hypotheses derived from Minsky for household behaviour, namely a positive partial derivative of $C$ with respect to property prices, is equivalent to that of Muellbauer. There are theoretical differences however. Muellbauer (2007) is based on rational life-cycle consumption while Minskyian households are becoming more optimistic due to endogenous animal spirits based on asset price cycles.
} 
investment will depend negatively on the wage share, residential investment may also react positively to changes in the wage share if wage earners own homes. The overall effect of the wage share on investment is thus ambiguous. Second, since housing is an especially visible expenditure, it is likely to be influenced by status comparison behaviour. Hence, if there were strong consumption cascades, we would also expect them to show in investment expenditures. Third, property prices are a cost for residential investment and thus rising housing wealth may have a negative effect. However, increasing property prices raise household wealth may improve access to credit (because of the rising value of collateral). This will have a positive effect on residential investment. Theoretically, the effect of housing wealth on investment is thus ambiguous.

Net exports are

$$
\begin{gathered}
N X=N X\left(Y, Y^{f}, E X, W S, W H\right) \\
\text { With } N X_{Y}, N X_{E x} N X_{W s,} N X_{W H}<0, N X_{Y f}>0
\end{gathered}
$$

$Y^{f}$ represents real foreign income and $E X$ is the nominal effective exchange rate. For net exports the close relationship of real unit labour costs and the wage share, justifies including the latter ${ }^{5}$. Since wages are driving the domestic price level and thus the country's international competitiveness, net exports are expected to depend negatively on the wage share. The influence of domestic and foreign income as well as the effective exchange rate is straight forward. Beside of that, rising housing wealth, via rising property prices, potentially influences domestic price competitiveness and thus exports.

Substituting equation 2,3 , and 4 into 1 , we can solve for equilibrium income, $Y^{*}$. The effect of a change in the wage share on $Y^{*}$ then is:

$$
\frac{d Y^{*}}{d W S}=\frac{f_{1}}{1-f_{2}}
$$

where $f_{1}=\left(\frac{\partial C}{\partial W S}+\frac{\partial I}{\partial W S}+\frac{\partial N X}{\partial W S}\right)$ and $f_{2}=\left(\frac{\partial C}{\partial Y}+\frac{\partial I}{\partial Y}+\frac{\partial N X}{\partial Y}\right)$. The short run effect is determined by $f_{1}$ which is private excess demand and represents the effect of a change in the functional income distribution given a certain level of income. $\frac{f_{1}}{1-f_{2}}$ is the multiplier that also includes the marginal effects of income on investment. If $f_{1}>0$ then the demand regime is called wage-led and profit-led if the effect is negative.

\footnotetext{
${ }^{5}$ In fact the AMECO database defines and computes real unit labour costs and the wage share at market prices identically.
} 
The effect of a change in $W H$ is expected to be positive, ${ }^{6}$ thus we do not distinguish between different regimes. However, we may wish to assess the relative actual impact of changes in income distribution and of changes in wealth variables.

The effect of $Q$ is a priory not clear. If status comparison plays an important role in households' (consumption and real estate purchase) decision making we expect a positive overall effect due to positive effects via consumption and residential investment. On the other hand if rising personal income inequality reduces aggregate consumption due to higher saving rates of more affluent households we expect a positive contribution overall.

In our empirical analysis we identify these regimes, based on the estimated partial effects. In addition we will also identify the relative contributions to actual growth attributable to these effects by multiplying the estimated coefficient with the actual change in the explanatory variable, e.g. $\hat{\beta}_{C W H} \Delta W H$, where $\hat{\beta}_{C W H}$ is the estimated coefficient of $W H$ on $C$, which is an estimate for the partial effect $\frac{\partial C}{\partial W H}$.

\section{The related empirical literature}

As our approach integrates considerations of functional income distribution, personal income distribution and wealth and debt, there is a potentially large and diverse literature that it is relevant. The first debate is that on wage-led or profit-led demand regimes. Bhaduri and Marglin (1990) has become a standard point of reference for the empirical literature. There are differences in the behavioural equations estimated as well as in econometric methodology. The first one relies on a system approach based on VAR models and often focuses on the mutual interaction between distribution and demand, but typically do not distinguish between effects on consumption and investment. Stockhammer and Onaran (2004), estimate five variable VARs for the US, UK and France using data from the early 1960s to the late 1990s and find weak evidence for wage-led demand. Barbosa-Filho and Taylor (2006) for the US from 1948-2002, Kiefer and Rada (2014) for 13 OECD countries from the 1970s to 2010 and Carvalho and Rezai (2014) for the US from 1967-2010, estimate two variable VARs and find profit-led demand. ${ }^{7}$ A second group applies a single equation approach where consumption, investment and the external sector functions are estimated separately. Papers covering several countries include Bowles and Boyer (1995), who cover fived OECD countries from the 1960s to 1987, Naastepad and Storm (2007) investigate eight OECD

\footnotetext{
${ }^{6}$ Theoretically the effect of housing wealth on investment could be negative. In this case a negative total effect could arise.

${ }^{7}$ Among these only Barbosa-Filho and Taylor present results for investment and consumption. They find large negative wage share results in the consumption function, which is at odds with their theoretical model.
} 
countries from 1960 to 2000, Hein and Vogel (2008) use data on six OECD countries from 1960 to 2005, Stockhammer and Stehrer (2011) estimate their model using data on 12 OECD countries from 1970 to 2007 and Onaran and Galanis (2012) investigate the G20 countries from 1960 to $2007 .{ }^{8}$ All these studies find wage-led domestic demand regimes for most countries. Third, Hartwig (2014) is the only study to use panel data (31 OECD countries, 1970 to 2011) to estimate a single equation approach and finds a slightly wage-led demand regime. Kiefer and Rada (2014) estimate demand and distribution equations for a panel of OECD countries with a set of control variables that shift income distribution and find that demand is profit-led. Neither Hartwig (2014) nor Kiefer and Rada (2014) control for wealth variables or personal income distribution. Most of the literature uses relatively simple specifications including disposable income, interest rates and the wage share as determinants in capital and investment functions. Onaran et al. (2011) is one of the few exceptions and will be discussed below.

Second, there is a growing theoretical literature that is employing the relative income hypothesis. Nevertheless there is of yet little empirical research that analyses its impact on aggregate consumption. ${ }^{9}$ Behringer and van Treeck (2013) use inequality as a variable explaining current account positions as well as household saving rates and find a negative effect for the G7 countries for the period 1972 to 2007. Brown (2004) offers a time series analysis of consumption expenditures for the USA covering the period 1978-2000, where he controls for current income and for inequality and finds a negative effect of inequality on consumption, which is at odds with Frank's argument. Carvalho and Rezai (2014) offer a theoretical model along the Bhaduri-Marglin lines with personal income distribution effects based on consumption cascades. Their empirical estimation uses a Threshold VAR, i.e. they split the sample according to periods of high and low personal inequality, but do not control for personal inequality directly, nor do they control for financial variables.

The large moves in financial as well as housing wealth, especially in the US, have led to renewed interest in the size of wealth effects, much of it is inspired by a neoclassical framework. In the basic formulations either financial wealth, housing wealth and debt or share and property prices are added to standard control variables (Girouard et al. 2006; Ludwig and Sløk 2004; Slacalek 2009). They find that the MPC out of housing wealth is higher compared to financial wealth in the US and UK, but that

\footnotetext{
${ }^{8}$ A series of later papers puts more focus on the estimation of the net export effects where real unit labour costs are driving price levels and thus are affecting exports and imports (Stockhammer et al. 2008; Onaran et al. 2011; Stockhammer et al. 2011).

${ }^{9}$ Neumark and Postlewaite (1998) and Bowles and Park (2005) use income and inequality measures to explain labour supply decisions. McBride (2001) reports the effects of relative income on self-reported happiness. Again on the micro level, Alvarez-Cuadrado et al. (2012) report that consumption is a positive function of average consumption of a geographical reference group. Thus an increase in inequality would decrease aggregate consumption.
} 
MPC out of housing wealth is often small and/or statistically insignificant in European countries. Moreover, wealth effects have been increasing with financial deregulation. In a variation emphasising the importance of credit availability Muellbauer (2007) working on the US, UK, South Africa and Japan and Aron et al. (2012) using data for the UK, US and Japan, stress the role of housing wealth in relaxing credit constraints. They show that for the USA and the UK measures of credit availability are a key driver of consumption.

Wealth and debt considerations have not played a major role in post-Keynesian analysis of consumption until recently. Indeed while there has been resurgence in the role of debt and financial instability, most contributions do not explicitly address consumption dynamics. For example Zhang and Bezemer (2014) investigate the effects of debt on growth for a panel of 37 countries over the period 1970 to 2012 and disaggregate debt by sector and according to whether it is stock-transaction related. They find a negative effect of debt. Kim et al. (2015) is one of the few exceptions that addresses consumption directly. They develop a post-Keynesian theory of consumption based on social norms, relative income considerations and rule of thumb behaviour. They estimate an aggregate consumption function for the USA 1952-2011 as a function of income, wealth, borrowing and other controls and find that borrowing has positive effects. Based on an SFC framework Zezza (2009) reports results for a private expenditure function, i.e. consumption plus investment, that is explained by financial assets, stock prices, housing wealth and the change in household and business debt, estimated using US data from 1970 to 2007. The specification does not include the level of household debt, nor does it include distributional variables.

The closest to our research question are Onaran et al. (2011). Onaran et al. (2011) introduce housing and financial wealth in a Bharduri-Marglin model and also distinguish between rentier and nonrentier profit incomes in order to control for the effects of financialisation. They find the US economy to be modestly wage-led and that growth has relied on wealth effects during periods of a declining wage share, using a sample covering the years 1962 to 2007. In a related paper Nishi (2012b) extends a Kaleckian model with rentiers for corporate borrowing and estimates a structural VAR including the profit share, capital accumulation and the debt ratio with quarterly data on Japan for the period 1992-2010. He finds Japan to be profit-led and debt burdened. Both do not control for personal income distribution and are restricted to one country each. Nishi only considers corporate debt, but not household debt or financial or housing wealth.

The empirical analyses of the effects of changes in income distribution and of changes in wealth have proceeded separately within post-Keynesian macroeconomics. While there is a high degree of coherence in modelling of functional income distribution, there is disagreement over the effects of changes in the wage share and of personal income distribution. There is as of yet hardly any 
empirical results on expenditure cascades at the macroeconomic level. Although Post-Keynesian economics has produced some highly original works on the role of debt and wealth, in its empirical analysis it does lag behind the mainstream, which has produced a substantial literature on wealth effects and consumption.

\section{Data and econometric method}

Our data set covers 18 OECD member countries from 1980 to 2013 on an annual basis ${ }^{10}$. Definitions and data sources are provided in Table A1 in the Appendix. We use real GDP $(Y)$ as well as private final consumption $(C)$, gross fixed capital formation $(I)$, exports of goods and services $(X)$ and imports of goods and services $(M)$ at 2005 market prices in billions of national currency. These variables, the corresponding deflators and the adjusted wage share at current factor costs $(W S)$ are taken from the Annual Macro-Economic database (AMECO). Real long term interest rates ( $i$ ) are taken from AMECO and OECD's Main Economic Indicator (MEI) database. Credit to households $(D H)$, credit to the business sector $(D B)$, real property prices $(P P)$ and trade weighted effective exchange rates $(E X)$ are from the Bank for International Settlements (BIS). We use a Gini index estimated from Theil index wage dispersion data from the University of Texas Inequality Project (EHII) as well as Gini coefficient (Gini) and the share of richest $1 \%$ of households (Top 1 ) from the Standardized World Income Inequality Database. The IMF's International Financial Statistics and the OECD's MEI database are the sources for the stock price series $(S P)$. The latter is deflated using the CPI from the AMECO database. Real GDP of OECD countries $\left(Y^{f}\right)$ is also taken from OECD's MEI database.

We use real property and stock price indices as proxies for housing wealth and financial wealth of the household sector, because wealth data is not available (for sufficiently long time periods) for most countries. This is common in the literature estimating wealth effects ${ }^{11}$, but it only captures price indices but not quantity changes.

Our panel has a small $\mathrm{N}$ as well as a small $\mathrm{T}(\mathrm{N}=18, \mathrm{~T}=33)$, which leads to econometric issues that are distinct from much of the panel literature which assumes a very large $\mathrm{N}$ and small $\mathrm{T}$. Our econometric baseline specification is thus a first difference (FD) estimator and we perform a several robustness checks. In our panel time series issues such as non-stationary regressors and unit roots are important. Indeed, panel unit root tests (Choi 2001) indicate that the logarithmized data in levels exhibit unit roots. After first differencing, the null hypothesis that all series contain a unit root can be rejected for all variables (see Appendix Table A3). Based on these results we prefer the FD estimator

\footnotetext{
${ }^{10}$ The countries included are: Austria, Australia, Belgium, Canada, Switzerland, Germany, Denmark, Spain, Finland, France, Ireland, Italy, Japan, Netherlands, Norway, Sweden, United Kingdom and the US.

${ }^{11}$ See Paiella (2009), Attanasio and Weber (2010) and Cooper and Dynan (2014) for recent surveys.
} 
to the standard within-panel transformation since both allow for country fixed effects but the former is more reliable with non-stationary data. The non-stationarity of our data set is also a reason not to use the widely used dynamic system GMM procedure (Blundell and Bond 1998) since it requires mean-stationary series (Baltagi 2013, p.167).

To address potential problems of autocorrelation in dynamic specifications we apply the Anderson and Hsiao (1982) (A\&H) estimator as well as restricted versions of one-step Arellano and Bond (1991) as robustness checks. With the popular difference (Arellano and Bond 1991) and system GMM (Blundell and Bond 1998) estimators the set of instruments required to handle the correlation of the lagged dependent variable with the error term (Nickell 1981) exhibits quadratic increase in $T$ and thus these methods become unfeasible when $T$ gets large in relation to $N$. We do not use the system GMM estimator because it requires mean stationarity in levels (Baltagi 2013, p.167), which is not satisfied in our dataset. We also experimented with cointegration specifications (available upon request). Results were qualitatively similar to the FD estimator, but the results are not robust and cointegration relations are usually very weak.

To investigate the sensitivity of our results to the pooling assumption we compare our results to those of the mean group (MG) estimator of Pesaran and Smith (1995). The MG approach estimates an individual model for each unit and averages across them. Thus one obtains an average estimate as with a pooled procedure but without a priori restricting the coefficients to be identical for each country. If the estimated parameters were strongly heterogeneous across units, the MG estimator and its standard errors would differ from a pooled regression.

\section{Results}

\subsection{Consumption function}

The consumption function we are estimating is of the following form:

$$
\begin{gathered}
\ln \left(C_{i t}\right)=\beta_{1} \ln \left(Y_{i t}\right)+\beta_{2} \ln \left(W S_{i t}\right)+\beta_{3} \ln \left(D H_{i t}\right)+\beta_{4} \ln \left(P P_{i t}\right)+ \\
\beta_{5} \ln \left(S P_{i t}\right)+\beta_{6} \ln \left(Q_{i t}\right)+\mu_{i}+v_{i t}
\end{gathered}
$$

where $\mu_{i}$ are country fixed effects ${ }^{12}$. Heteroskedasticity and autocorrelation robust standard errors are used in all specifications. We estimate equation 7 using different techniques and the results are summarised in Table 2. The first four columns report variations of a FD estimator with varying control variables. Specification 2 uses a Gini index and specification 3 a Theil index based estimated Gini instead of the income share of the richest $1 \%$ of households in order to measure the personal income

\footnotetext{
${ }^{12}$ Due to our limited sample size we were not able to include country and time fixed effects simultaneously, especially with the dynamic specifications. Adding time dummies only proved to be relevant for the crisis years anyway and including them did not change our results. Results are available upon request.
} 
distribution. Specification 4 focuses on the role of debt rather than assets and includes household debt in differences as well as in levels in order to allow for negative stock and positive flow effects. Specification 5 employs the MG estimator in order to assess the robustness of the FD estimator with respect to the assumption of homogeneous coefficients across countries. Specification 6 reports a dynamic specification using the A\&H estimator and specification 7 the difference GMM estimator. Both have been restricted to two lags for instrumenting $C_{t-1}$ in order to keep the number of instruments in an acceptable relation to our limited sample size. In general, results are robust across specifications, however the difference GMM estimator does not pass the overidentification tests, pointing to endogeneity problems with the instruments. Also the simple OLS version of the A\&H estimator barely passes these diagnostic tests. Therefor our preferred estimator is first differences (column 1). Overall, the main results are similar across the static specifications, and we interpret the similar results of our preferred specification (1) and the MG estimator (5) as support for our decision to pool the data.

[Table 2]

The most robust result is the (long-run ${ }^{13}$ ) income elasticity of about 0.7 , which is of an expected magnitude. A $1 \%$ increase in the wage share has a direct (long-run) effect on consumption of about $0.14 \%$ across the static specifications. Household debt, as well as property prices have positive impacts on consumption with elasticities of about 0.1 and 0.02 , respectively. When testing for differences between stock and flow effects in household debt (specification 4), we do find statistically significant positive effects for debt levels, representing the stock effect, as well as for changes, representing the flow effect. While the latter result is in line with the hypothesis of debt stock and flow effects, a positive stock effect is not and we therefore focus on the specifications not distinguishing between the two. Since mortgage debt dominates household debt measures, we interpret the pronounced effect of the latter as evidence for the importance of housing wealth and equity withdrawals in financing consumer spending. Surprisingly the variable which captures these effects directly, the property price index, turns out statistically insignificant and with a much smaller estimated partial effect compared to household debt levels. The reason might be that rising property prices are a prerequisite for equity withdrawals but that the actual decision of households to withdraw equity for consumption purposes are influenced by other factors independent of property prices. Stock prices have no statistically significant effect on consumption. Estimated effects are small in all specifications and turn negative in some cases.

\footnotetext{
${ }^{13}$ The coefficients in the dynamic specification are transformed to long run effects by multiplying them with $1 /\left(1-\beta_{C}\right)$ where $\beta_{c}$ is the coefficient on $C_{t-1}$.
} 
To assess consumption cascades, we include three different measures of the personal income distribution. However neither the income share of the top $1 \%$ of households nor any of the income Gini-coefficients are statistically significant in any of our specifications. Hence, we do not find evidence for consumption cascades.

The main findings from the analysis of the consumption function can be summarized as follows: First, the wage share has statistically significant positive effects on consumption expenditures. The size of that effect is modest but robust across specifications. Second, household debt seems to be the most important financial variable in explaining consumer behaviour. This result is also robust across specifications. We fail to find evidence for different stock and flow effects of debt. Third, property prices have small and often statistically insignificant effects. Housing wealth effects seem to be captured by the debt measure since consuming housing wealth requires taking on additional mortgages. Fourth, share prices have no statistically significant effect on consumption. Fifth, we fail to find evidence for an effect of personal income inequality on aggregate consumption spending.

\subsection{Investment function}

The investment function takes the following form:

$$
\begin{gathered}
\ln \left(I_{i t}\right)=\beta_{1} \ln \left(Y_{i t}\right)+\beta_{2} i_{i t}+\beta_{3} \ln \left(W S_{i t}\right)+\beta_{4} \ln \left(D H_{i t}\right)+\beta_{5} \ln \left(D B_{i t}\right)+ \\
\beta_{6} \ln \left(P P_{i t}\right)+\beta_{5} \ln \left(S P_{i t}\right)+\beta_{6} \ln \left(Q_{i t}\right)+\mu_{i}+v_{i t}
\end{gathered}
$$

again with country fixed effects $\mu_{i}$ and in addition to those variables already used in the consumption function also a long-term real interest rate $(i)$ and non-financial corporate business debt $(D B)$. Equation (8) is estimated including only 16 instead of 18 countries since our data set does not contain information on business debt for Switzerland and Ireland. The specification above is augmented by lags of the dependent variable as well as lags of exogenous regressors (Table 3). In estimating equation 8 we start with a baseline first difference approach (specification 1 ) and then add additional controls or use different estimation techniques. Specification 2 uses a Gini coefficient instead of top income shares, in specification 3 asset prices are dropped in favour of debt stock and flow effects. Specification 4 applies the MG estimator and specifications 5 and 6 the A\&H and the difference GMM estimator, again with limited lag length for instruments. A\&H does not pass the Hansen overidentification restriction test and we thus do not consider it further. The GMM estimator passes the overidentification restriction test and first order autocorrelated errors are reported as required in the case of a properly specified dynamic first difference estimator. However the estimated coefficient on lagged investment is almost 1.1 implying not only a unit root problem but also an explosive dynamic. Overall, the results are reasonably robust across specifications, however not as stable as in the case of the consumption function. Due to the weak performance of the dynamic specifications, our preferred estimator is again the static FD estimator (specification 1). 
Results reported in Table 3 are as follows: Income has a very strong impact on investment spending with an elasticity well above 1 . This finding is robust across all specifications. The (long-run) elasticity with respect to the wage share is about 0 in the first differences specifications and negative in the dynamic ones. Long term real interest rates affect investment expenditures negatively in all specifications. Property prices have a positive impact in all specifications ranging from 0.04 to 0.28 , pointing to the importance of property prices for residential investment spending. Household as well as business debt have mostly negative effects. If the change in household and business debt is added (specification 3), the estimated coefficients on debt changes are positive, and in the case of household debt statistically significant, whereas the level effect for household debt turns positive. Thus we do not find evidence for negative stock effects of either household or business debt in the investment function when level and changes in levels are considered. Nevertheless using only levels, yields robust negative effects of household debt. In contrast to the income share of the richest $1 \%$ of households, the Gini index turns out to be statistically significant with a negative effect. We conclude that relative consumption, with respect to housing, does not feed through to aggregate (residential) investment spending decisions. The latter scenario occurs if housing itself is subject to conspicuous consumption, as found in the literature (Heffetz 2011), and thus could be driven by income inequality. Stock prices have small and statistically insignificant effects in the static specifications. A considerable part of total capital formation relies on household spending decisions and therefor partially explains zero or positive effects of the wage share on total investment as well as negative effects of household debt.

[Table 3]

The key findings regarding the investment function are the following: First, it is not straightforward to find negative effects of the wage share on investment. In some specifications we obtain positive elasticities which seem to be the result of positive wage share effects on capital formation in the construction sector. Our preferred specification yields effectively zero long-run effects of the wage share. Second, property prices influence investment spending positively, pointing to the positive effect of property price booms on residential investment. Third, the negative effect of household debt indicates that higher debt levels prevent households from residential investment spending. Fourth, the personal distribution of income, measured by the income share of the richest $1 \%$ of households and the income Gini coefficient, is either not statistically significant or exhibits a negative effects, not supporting Veblen effects.

\subsection{External sector}

The external sector was modelled by estimating an export as well as an import equation. Both proved to be robust with respect to different estimation procedures. For brevity Table 4 only reports 
the FD estimator and the dynamic A\&H estimator. The long-run elasticity of exports with respect to foreign demand $\left(Y^{f}\right)$ is about 2 , independent of the specification. These export elasticities seem to be influenced by a trend of globalization since income elasticities of exports well beyond 1 are not plausible in the long run. As expected, the elasticity of exports with respect to the wage share is negative and lies between -0.16 and -0.25 . The elasticity with respect to the nominal effective exchange rate is negative and thus is in line with expectations (i.e. appreciations of the domestic currency leading to lower exports). Property prices have a negative impact on exports of about 0.1 which can be interpreted as their contribution to domestic inflation and thus increasing export costs.

[Table 4]

The income elasticity of imports is about 1.3. The effect of the wage share is not statistically significant and about 0 . Exchange rates have a statistically significant positive effect, as expected. Property prices also statistically significantly affect imports in a positive way. Rising property prices might drive up the domestic price level and thus encourage imports, ceteris paribus. The export elasticity of imports is about 0.35 . The import equation includes exports to reflect the dependence of exports on imported raw materials and intermediary goods. Results are similar if exports are excluded.

\subsection{Demand regimes and the drivers of medium term growth ${ }^{14}$}

Table 5 summarises the key results regarding demand regimes. It is based on the preferred FD estimates (specification 1 in Table 3, 4 and 5). Elasticities have been transformed into marginal effects and normalized by income to make them comparable. For example the marginal effect of the wage share reported in Table 5 is computed in the following way:

$$
\frac{\partial Y^{P E D}}{\partial W S} \frac{1}{Y}=\hat{\beta}_{C, W S}\left(\varnothing \frac{C}{Y}\right) \frac{1}{\varnothing W S}+\hat{\beta}_{I, W S}\left(\varnothing \frac{I}{Y}\right) \frac{1}{\varnothing W S}+\hat{\beta}_{X, W S}\left(\varnothing \frac{X}{Y}\right) \frac{1}{\varnothing W S}+\hat{\beta}_{M, W S}\left(\varnothing \frac{M}{Y}\right) \frac{1}{\varnothing W S}
$$

$\hat{\beta}_{-}, W S$ is the estimated elasticity of consumption, investment spending, exports or imports with respect to the wage share. $\varnothing \frac{C}{Y}$ represents the GDP weighted average of the consumption-to-income ratio of the 18 countries included in the panel and similarly $\emptyset W S$ is the GDP weighted average of the wage share. So first GDP weighted averages (based on PPPs) of $C / Y, I / Y, X / Y$ and $M / Y$ are computed for each year. In a second step simple averages of these yearly averages are computed.

\footnotetext{
${ }^{14}$ We use the terms economic growth and growth contributions as they are used in the context of the Nationa Accounts, where growth contributions are defined as the year on year changes of GDP components relative to GDP. This should not be confused with the equilibrium growth rates that growth theory. Specifically we will be calculating growth contributions for the 10 year period from 1997 to 2007. .
} 
Row 4 adds the effect of a 1\%-point change in the wage share on private excess demand, $Y^{P E D}$, which is numerator of equation (5), $f_{1}$, and determines the sign of the effect of changes in distribution on equilibrium demand. It can be thought of as the first round effect or the sum of the partial effect, given a certain level of income. The second round effects include the indirect effect as the first round effects increase income and thus induce additional expenditures.

[Table 5]

There are several interesting patterns. First, the domestic effects of the wage share on consumption and investment are similar across countries. Demand regimes in all countries are domestically wage led. Second, there is a substantial difference of the net export effects that directly corresponds to the degree of openness, i.e. exports plus import relative to $\mathrm{GDP}^{15}$. A large and relatively closed economy like the USA has a small net export effect and is overall strongly wage led. Medium sized open economies like France, or Germany have substantially smaller effects. In small open economies like Austria or the Netherlands the negative external sector effects become so large that the total demand regime can become profit led.

Finally we want turn to the question which variables have been the main drivers of growth in the decade prior to the 2007 crisis. Table 6 reports to what extent the change of explanatory variables, explain the change in consumption and investment spending in the period 1997-2007. In addition to the full panel we also take a look at four country groups: Anglo-American (Australia, Canada, the United Kingdom and the United States), Euro-North (Austria, Belgium, Germany, Finland, and the Netherlands), Euro-South (Spain, Italy and Ireland) and non-Euro-North (Denmark, Switzerland, Norway and Sweden). These country groupings are motivated by the hypothesis that distinct growth models have emerged in the form of a debt-driven model in the Anglophone countries and the southern European countries and an export-driven model in the Nordic countries (Stockhammer 2009; Hein 2012b). This distinction should lead to distinct pattern of demand formation.

[Table 6]

Consumption and investment grew much slower in the Euro-North group than in the other groups. Rows 1 and 5 calculate the growth in consumption and investment that is not explained by income growth. While consumption expanded more slowly than income in the Euro-North group, there is a substantial unexplained gap in consumer spending by income for the other groups $(17.4 \%, 8.8 \%$ and $8.8 \%$ of GDP for the Anglophone, Euro-South and non-Euro-North groups respectively). The

\footnotetext{
${ }^{15}$ Openness is computed as the average of nominal exports and imports to nominal GDP. We evaluate export and import shares at sample average and assume that current account is in balance.
} 
unexplained gap spending for investment (row 5) amounts to $11.8 \%$ and $8.5 \%$ of GDP in case of EuroSouth and non-Euro-North. ${ }^{16}$ Changes in the wage share hardly explain any of these dynamics. The contributions are less than $1 \%$ for consumption (row 2 ) and effectively 0 for investment (row 6 ). The same holds true for the income share of the top 1\% (rows 4 and 8 ). In contrast changes in property prices, stock prices and debt (row 3 ) explains a rise in consumer spending of $12.8 \%, 10.2 \%$ and $20.4 \%$ for the Anglophone, non-Euro-North and Euro-South groups. In the case of investment (row 7) these asset variables explain $11.9 \%$ and $11.4 \%$ for Anglophone and non-Euro-North while they did not affect or even diminished investment spending in the other two groups. Rows 9, 10 and 11 calculate the contributions of the differential between domestic and foreign demand, the wage share and property prices on net export. Rows 12-14 combine the consumption, investment and net export effects to compute a short-run private excess demand effect $^{17}$ that can be attributed to asset dynamics (row 13), the wage share (row 12) and personal income inequality (row 13). Rows 15-17, (based on equation 5$)^{18}$, do the same for equilibrium income, which takes into account the multiplier mechanism. Asset effects contributed almost 20\% to GDP growth in the Anglophone economies and $13 \%$ in Euro-South, but only $1.4 \%$ in Euro-North and $3 \%$ in non-Euro-North. The differences in the underlying multipliers are driven by the varying degrees of openness to trade. Anglophone and EuroSouth which are more closed in comparison to the two North groups have larger multipliers.

The results summarised in Table 6 illustrate that the panel results that pool parameters can explain very different country group performances. These are due to varying degrees of openness and different asset price and debt dynamics. The direct effects of distributional shifts were negligible. Property prices and household debt played the dominant role in explaining growth prior to the crisis.

\section{Conclusions}

The paper has investigated the role of functional and personal income distribution as well as the role of wealth and debt in consumption and investment. The basis for this was an extended Bhaduri and Marglin (1990) model. The econometric analysis was based on a sample of 18 OECD countries for the period 1980-2013. We have four major findings. First, we do find statistically significant effects of the functional income distribution on consumption and investment. These effects are modest in size, but qualitatively, we find wage-led domestic demand.

\footnotetext{
${ }^{16}$ Row 5 calculates the part of investment growth that is not explained changes in income and the interest rate.

${ }^{17} \mathrm{Y}$-SR is constructed by summing up the consumption, investment and net export effects weighted by consumption, investment and net exports relative to GDP.

${ }^{18}$ The multipliers are 1.77 for the overall panel and 2.16, 1.11, 1.09 and 1.53 for Anglophone, Euro-North, nonEuro-North and Euro-South, respectively. The long run effects (Y-LR) then result from the short run (Y-SR) effects times the corresponding multipliers.
} 
Second, we fail to find effects for personal income distribution, measured by top incomes shares or Gini coefficients. It is possible that negative effects of inequality due to lower consumption propensities of the rich are offset by positive imitation effects stressed by the Veblen tradition. Alternatively it might also be the case that consumers do care about consumption of their peers but rising property prices provided the necessary collateral to take on debt for financing these expenditure cascades.

Third, we find statistically significant and robust positive effects of household debt on consumption. This is at odds with the standard view of the role of wealth, which would expect a negative partial effect of household debt. We fail to find different effects for debt as a stock and as flow variable. We do find negative effects of household debt on investment (which includes residential investment). Real property prices have strong positive and statistically significant effects in the investment function, whereas they only play a limited role for consumption.

Forth, to analyse economic significance we have calculated the contributions of key variables to consumption and investment growth in the decade prior to the crisis (1998-2007). This indicated that functional and personal income distribution have negligible effects, whereas property prices and household debt have had strong positive contributions. This is in line with the hypothesis of an asset price-driven (or debt-driven) growth model in explaining growth prior to the 2007 crisis.

\section{Bibliography}

Alvarez-Cuadrado, F., Casado, J.M., Labeaga, J.M. and Sutthiphisal, D. 2012. Envy and habits: Panel data estimates of interdependent preferences. Bank of Spain Working Paper 1213.

Anderson, T. and Hsiao, C. 1982. Formulation and estimation of dynamic models using panel data. Journal of Econometrics, 18(1), pp.47-82.

Arellano, M. and Bond, S. 1991. Some Tests of Specification for Panel Data: Monte Carlo Evidence and an Application to Employment Equations. Review of Economic Studies, 58(2), pp.277-297.

Aron, J., Duca, J.V., Muellbauer, J., Murata, K. and Murphy, A. 2012. Credit, Housing Collateral, and Consumption: Evidence From Japan, the U.K., and the U.S. Review of Income and Wealth, 58(3), pp.397-423.

Atkinson, A.B., Piketty, T. and Saez, E. 2011. Top Incomes in the Long Run of History. Journal of Economic Literature, 49(1), pp.3-71.

Attanasio, O.P. and Weber, G. 2010. Consumption and Saving: Models of Intertemporal Allocation and Their Implications for Public Policy. Journal of Economic Literature, 48(3), pp.693-751.

Baltagi, B. 2013. Econometric Analysis of Panel Data 5th ed., Wiley. 
Barbosa-Filho, N.H. and Taylor, L. 2006. Distributive and demand cycles in the US economy-a structuralist Goodwin model. Metroeconomica, 57(3), pp.389-411.

Behringer, J. and van Treeck, T. 2013. Income distribution and current account: A sectoral perspective. IMK Working Paper 125.

Belabed, C.A., Theobald, T. and van Treeck, T. 2013. Income distribution and current account imbalances. IMK Working Paper 126.

Bhaduri, A. 2011. A contribution to the theory of financial fragility and crisis. Cambridge Journal of Economics, 35(6), pp.995-1014.

Bhaduri, A. and Marglin, S. 1990. Unemployment and the real wage: the economic basis for contesting political ideologies. Cambridge Journal of Economics, 14(4), pp.375-393.

Blundell, R. and Bond, S. 1998. Initial conditions and moment restrictions in dynamic panel data models. Journal of Econometrics, 87(1), pp.115-143.

Bowles, S. and Boyer, R. 1995. Wages, aggregate demand, and employment in an open economy: an empirical investigation. In G. Epstein \& H. Gintis, eds. Macroeconomic policy after the conservative era: Studies in investment, saving and finance.

Bowles, S. and Park, Y. 2005. Emulation, Inequality, and Work Hours: Was Thorsten Veblen Right?. The Economic Journal, 115(1996), pp.397-412.

Brown, C. 2004. Does income distribution matter for effective demand? Evidence from the United States. Review of Political Economy, 16(3), pp.291-307.

Buiter, W.H. 2010. Housing Wealth Isn't Wealth. Economics: The Open-Access, Open-Assessment EJournal, 4(2010-22).

Carvalho, L. and Rezai, A. 2014. Personal Income Inequality and Aggregate Demand. FEA-USP Working Paper 2014-23.

Charles, S. 2008. Teaching Minsky's financial instability hypothesis: a manageable suggestion. Journal of Post Keynesian Economics, 31(1), pp.125-138.

Choi, I. 2001. Unit root tests for panel data. Journal of International Money and Finance, 20(2), pp.249-272.

Cooper, D. and Dynan, K. 2014. Wealth Effects and Macroeconomic Dynamics. Journal of Economic Surveys, Advance Ac. Available from: http://onlinelibrary.wiley.com/doi/10.1111/joes.12090/abstract

Davidson, P. 1972. Money and the real world. Economic Journal, 82(325), pp.101-115.

Duesenberry, J.S. 1949. Income, Saving and the Theory of Consumer Behavior, Harvard University Press.

Dutt, A.K. 2006. Maturity, Stagnation and Consumer Debt: a Steindlian Approach. Metroeconomica, 57(3), pp.339-364. 
Fazzari, S., Ferri, P. and Greenberg, E. 2008. Cash flow, investment, and Keynes-Minsky cycles. Journal of Economic Behavior and Organization, 65(3), pp.555-572.

Frank, R. 1985. The demand for unobservable and other nonpositional goods. The American Economic Review, 75(1), pp.101-116.

Frank, R.H., Levine, A.S. and Dijk, O. 2014. Expenditure Cascades. Review of Behavioral Economics, 1(1-2), pp.55-73.

Girouard, N., Kennedy, M. and André, C. 2006. Has the rise in debt made households more vulnerable? OECD Working Paper 2006-63.

Godley, W. and Lavoie, M. 2007. Monetary Economics, New York: Palgrave Macmillan.

Goodwin, R.M. 1967. A Growth Cycle. In C. H. Feinstein, ed. Socialism, Capitalism and Economic Growth. Cambridge: Cambridge University Press.

Hartwig, J. 2014. Testing the Bhaduri-Marglin model with OECD panel data. International Review of Applied Economics, 28(4), pp.419-435.

Heffetz, O. 2011. A test of conspicuous consumption: Visibility and income elasticities. Review of Economics and Statistics, 93(4), pp.1101-1117.

Hein, E. 2012a. Finance-dominated Capitalism, Re-distribution, Household Debt And Financial Fragility In A Kaleckian Distribution And Growth Model. PSL Quarterly Review, 65(260), pp.1151.

Hein, E. 2012b. The Macroeconomics of Finance-Dominated Capitalism - And Its Crisis, Cheltenham: Edward Elgar.

Hein, E. and Vogel, L. 2008. Distribution and growth reconsidered: empirical results for six OECD countries. Cambridge Journal of Economics, 32(3), pp.479-511.

Isaac, A.G. and Kim, Y.K., 2013. Consumer and Corporate Debt: A Neo-Kaleckian Synthesis. Metroeconomica, 64(2), pp.244-271.

Kalecki, M. 1954. Theory of Economic Dynamics Collected . J. Osiatynski, ed., Oxford: Clarendon Press.

Kapeller, J. and Schütz, B. 2014. Debt, boom, bust: a theory of Minsky-Veblen cycles. Journal of Post Keynesian Economics, 36(4), pp.781-814.

Keen, S. 1995. Finance and economic breakdown: modeling Minsky's "financial instability hypothesis." Journal of Post Keynesian Economics, 17(4), pp.607-635.

Keynes, J.M., 1973. The General Theory of Employment, Interest and Money. The collected writings of John Maynard Keynes volume VII, Cambridge: Macmillan.

Kiefer, D. \& Rada, C. 2014. Profit maximising goes global: the race to the bottom. Cambridge Journal of Economics, Advance Ac. Available from: http://cje.oxfordjournals.org/content/early/2014/09/25/cje.beu040.abstract. 
Kim, Y.K., Setterfield, M. and Mei, Y. 2015. Aggregate consumption and debt accumulation: an empirical examination of US household behaviour. Cambridge Journal of Economics, 39(1), pp.93-112.

Ludwig, A. and Sløk, T. 2004. The relationship between Stock Prices, House Prices and Consumption in OECD Countries, The B.E. Journal of Macroeconomics, 4(1), pp.1-28.

McBride, M. 2001. Relative-income effects on subjective well-being in the cross-section. Journal of Economic Behavior \& Organization, 45(3), pp.251-278.

Minsky, H.P. 1995. The Financial Instability Hypothesis: A Restatement. In P. Arestis \& T. Skouras, eds. Post Keynesian Economic Theory. Sussex: Wheatsheaf Books, pp. 24-55.

Muellbauer, J.N. 2007. Housing, Credit and Consumer Expenditure. In Proceedings - Economic Policy Symposium - Jackson, Hole, Federal Reserve Bank of Kansas City, pp. 267-334.

Naastepad, C. and Storm, S. 2007. OECD demand regimes (1960-2000). Journal of Post Keynesian Economics, 29(2), pp.211-246.

Neumark, D. and Postlewaite, A. 1998. Relative income concerns and the rise in married women's employment. Journal of Public Economics, 70(1), pp.157-183.

Nickell, S. 1981. Biases in Dynamic Models with Fixed Effects. Econometrica, 49(6), pp.1417-1426.

Nishi, H. 2012a. Household Debt, Dynamic Stability, and Change in Demand Creation Patterns. Review of Political Economy, 24(4), pp.607-622.

Nishi, H. 2012b. Structural VAR analysis of debt, capital accumulation, and income distribution in the Japanese economy: a Post Keynesian perspective. Journal of Post Keynesian Economics, 34(4), pp.685-712.

Onaran, Ö. and Galanis, G. 2012. Is aggregate demand wage-led or profit-led? National and global effects. ILO Conditions of Work and Employment Series No. 40.

Onaran, Ö., Stockhammer, E. and Grafl, L., 2011. Financialisation, income distribution and aggregate demand in the USA. Cambridge Journal of Economics, 35(4), pp.637-661.

Paiella, M. 2009. The Stock Market, Housing and Consumer Spending: a Survey of the Evidence on Wealth Effects. Journal of Economic Surveys, 23(5), pp.947-973.

Palley, T. 1994. Debt, aggregate demand and the business cycle: an analysis in the spirit of Kaldor and Minsky. Journal of Post Keynesian Economics. 16(3), pp. 371-390.

Pesaran, H.M. and Smith, R. 1995. Estimating long-run relationships from dynamic heterogeneous panels. Journal of Econometrics, 68(1), pp.79-113.

Ryoo, S. 2013. Minsky cycles in Keynesian models of growth and distribution. Review of Keynesian Economics, 1(1), pp.37-60.

Slacalek, J. 2009. What drives personal consumption? The role of housing and financial wealth. The BE Journal of Macroeconomics, 9(1), pp.1-35. 
Stockhammer, E. 2012. Financialization, income distribution and the crisis. Investigación Económica, 71(279), pp.39-70.

Stockhammer, E. 2009. The finance-dominated accumulation regime, income distribution and the present crisis. Papeles de Europa, 19, pp.58-81.

Stockhammer, E., Hein, E. and Grafl, L. 2011. Globalization and the effects of changes in functional income distribution on aggregate demand in Germany. International Review of Applied Economics, 25(1), pp.1-23.

Stockhammer, E. and Onaran, Ö. 2004. Accumulation, distribution and employment: a structural VAR approach to a Kaleckian macro model. Structural Change and Economic Dynamics, 15(4), pp.421-447.

Stockhammer, E., Onaran, O. and Ederer, S. 2008. Functional income distribution and aggregate demand in the Euro area. Cambridge Journal of Economics, 33(1), pp.139-159.

Stockhammer, E. and Stehrer, R. 2011. Goodwin or Kalecki in Demand? Functional Income Distribution and Aggregate Demand in the Short Run. Review of Radical Political Economics, 43(4), pp.506-522.

Zezza, G. 2009. Fiscal policy and the economics of financial balances. European Journal of Economics and Economic Policies, 6(2), pp.289-310.

Zhang, L. and Bezemer, D. 2014. How the Credit Cycle Affects Growth: The Role of Bank Balance Sheets, University of Groningen Faculty of Economics and Business Working Paper 14026-GEM. 


\section{Tables and Figures}

Figure 1. Macroeconomic trends 1980-2010

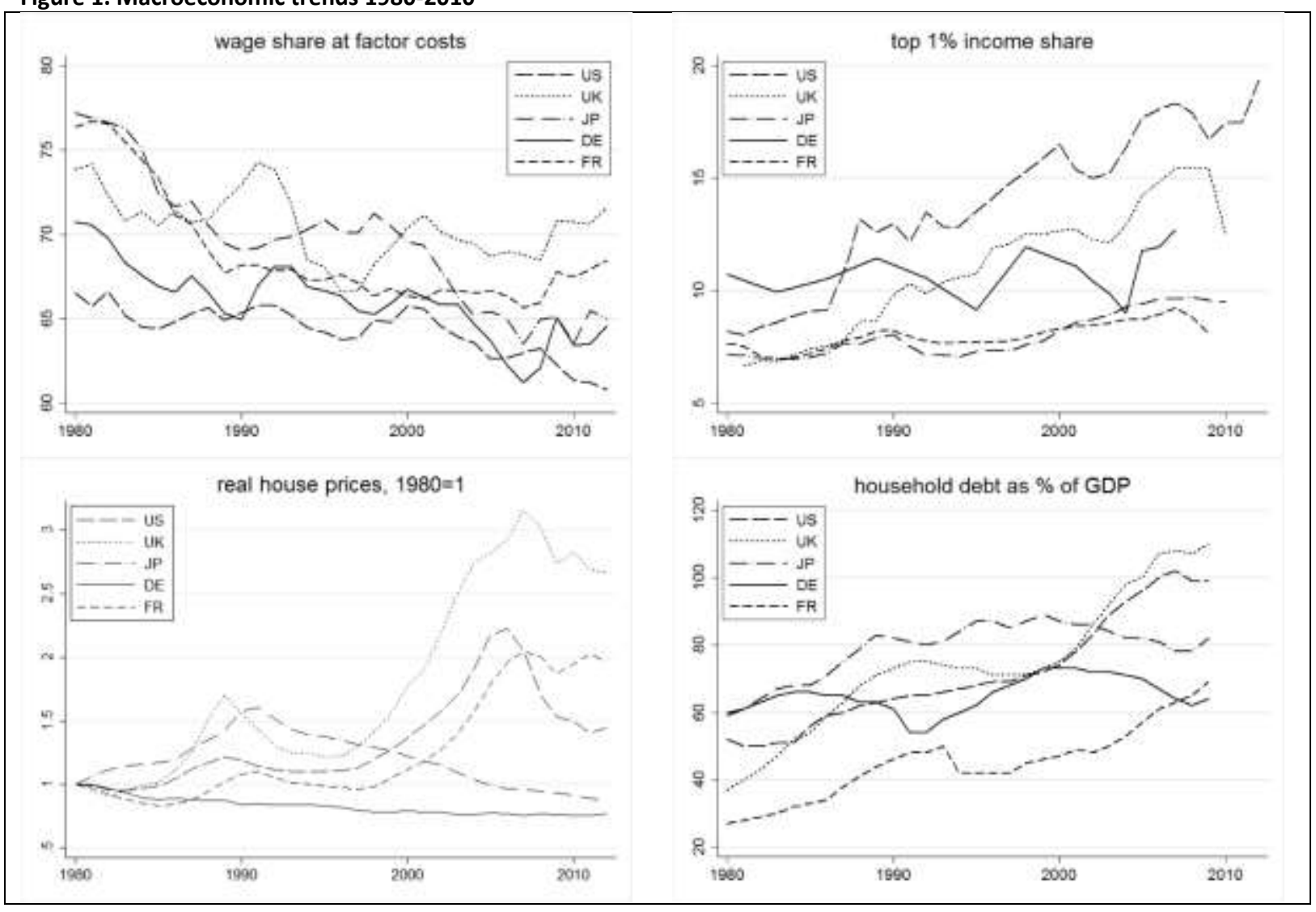


Table 1. Different consumption theories

\begin{tabular}{|c|c|c|}
\hline Hypothesis & \begin{tabular}{|c|} 
Theoretical Argument \\
\end{tabular} & Predicted signs \\
\hline the rich save more & $\begin{array}{l}\text { Inequality lowers consumption because } \\
\text { richer households have a higher } \\
\text { propensity to save. }\end{array}$ & $\frac{\partial C}{\partial Q}<0$ \\
\hline expenditure cascades & $\begin{array}{l}\text { Households make consumption } \\
\text { decisions with respect to richer peers. }\end{array}$ & $\frac{\partial C}{\partial Q}>0$ \\
\hline housing wealth is no wealth & $\begin{array}{l}\text { Rising house prices lead to wealth } \\
\text { effects for home owners and higher } \\
\text { savings of willing-to-be-homeowners. }\end{array}$ & $\frac{\partial C}{\partial W H}=0$ \\
\hline net wealth effect & $\begin{array}{l}\text { Net wealth (NW) is the relevant wealth } \\
\text { measure for consumption decisions. }\end{array}$ & $\frac{\partial C}{\partial(W H+W F)}=-\frac{\partial C}{\partial D H}$ \\
\hline credit constraints & $\begin{array}{l}\text { Due to credit constraints, changes in } \\
\text { housing wealth effect consumption } \\
\text { even if shocks are anticipated. }\end{array}$ & $\frac{\partial C}{\partial W H}>0$ and $\frac{\partial C}{\partial W H}>\frac{\partial C}{\partial W F}$ \\
\hline Minskyian households & $\begin{array}{l}\text { Rising asset prices lead to increasingly } \\
\text { optimistic lending and spending. }\end{array}$ & $\frac{\partial C}{\partial W H}>0$ \\
\hline stock and flow effects of debt & $\begin{array}{l}\text { The stock of debt implies interest rate } \\
\text { payments which affect consumption } \\
\text { negatively whereas the flow of debt } \\
\text { affects consumption positively. }\end{array}$ & $\frac{\partial C}{\partial D H}<0$ and $\frac{\partial C}{\partial \Delta D H}>0$ \\
\hline
\end{tabular}


Table 2. Consumption function, dependent variable: $\log \left(C_{t}\right)$

\begin{tabular}{|c|c|c|c|c|c|c|c|}
\hline & (1) & (2) & (3) & (4) & (5) & (6) & (7) \\
\hline & FD & FD & FD & FD & MG & $A \& H$ & GMM \\
\hline $\log (C)_{t-1}$ & & & & & & $\begin{array}{c}0.248^{* * *} \\
(0.09)\end{array}$ & $\begin{array}{c}0.373^{* * *} \\
(0.12)\end{array}$ \\
\hline $\log (Y)_{t}$ & $\begin{array}{c}0.710^{* * *} \\
(0.07)\end{array}$ & $\begin{array}{c}0.716^{* * *} \\
(0.06)\end{array}$ & $\begin{array}{c}0.806^{* * *} \\
(0.08)\end{array}$ & $\begin{array}{c}0.718^{* * *} \\
(0.06)\end{array}$ & $\begin{array}{c}0.633^{* * *} \\
(0.09)\end{array}$ & $\begin{array}{c}0.593 * * * \\
(0.10)\end{array}$ & $\begin{array}{c}0.569 * * * \\
(0.15)\end{array}$ \\
\hline $\log (W S)_{t}$ & $\begin{array}{c}0.136^{*} \\
(0.08)\end{array}$ & $\begin{array}{c}0.136 * \\
(0.08)\end{array}$ & $\begin{array}{l}0.141 \\
(0.09)\end{array}$ & $\begin{array}{c}0.154^{*} \\
(0.08)\end{array}$ & $\begin{array}{c}0.144^{* *} \\
(0.07)\end{array}$ & $\begin{array}{l}0.072 \\
(0.07)\end{array}$ & $\begin{array}{l}0.078 \\
(0.08)\end{array}$ \\
\hline $\log (P P)_{t}$ & $\begin{array}{l}0.017 \\
(0.01)\end{array}$ & $\begin{array}{c}0.021^{* *} \\
(0.01)\end{array}$ & $\begin{array}{l}0.011 \\
(0.01)\end{array}$ & & $\begin{array}{l}0.013 \\
(0.03)\end{array}$ & $\begin{array}{c}0.027^{* * *} \\
(0.01)\end{array}$ & $\begin{array}{c}0.027^{* *} \\
(0.01)\end{array}$ \\
\hline $\log (S P)_{t}$ & $\begin{array}{l}-0.002 \\
(0.00)\end{array}$ & $\begin{array}{l}-0.001 \\
(0.00)\end{array}$ & $\begin{array}{l}-0.003 \\
(0.00)\end{array}$ & & $\begin{array}{l}0.009 \\
(0.01)\end{array}$ & $\begin{array}{l}0.003 \\
(0.00)\end{array}$ & $\begin{array}{l}0.004 \\
(0.00)\end{array}$ \\
\hline $\log (\mathrm{DH})_{\mathrm{t}}$ & $\begin{array}{c}0.110 * * * \\
(0.02)\end{array}$ & $\begin{array}{c}0.105^{* * *} \\
(0.02)\end{array}$ & $\begin{array}{c}0.085 * * * \\
(0.02)\end{array}$ & $\begin{array}{c}0.114^{* * *} \\
(0.02)\end{array}$ & $\begin{array}{c}0.128 * * * \\
(0.02)\end{array}$ & $\begin{array}{c}0.049 * * \\
(0.02)\end{array}$ & $\begin{array}{l}0.011 \\
(0.03)\end{array}$ \\
\hline$\Delta \log (\mathrm{DH})_{\mathrm{t}}$ & & & & $\begin{array}{c}0.038^{*} \\
(0.02)\end{array}$ & & & \\
\hline $\log (\mathrm{TOP} 1)_{\mathrm{t}}$ & $\begin{array}{l}0.008 \\
(0.01)\end{array}$ & & & $\begin{array}{l}0.008 \\
(0.01)\end{array}$ & $\begin{array}{l}-0.017 \\
(0.03)\end{array}$ & $\begin{array}{l}0.008 \\
(0.01)\end{array}$ & $\begin{array}{l}0.007 \\
(0.01)\end{array}$ \\
\hline $\log (\mathrm{GINI})_{\mathrm{t}}$ & & $\begin{array}{l}0.027 \\
(0.02)\end{array}$ & & & & & \\
\hline $\log (E H I I)_{t}$ & & & $\begin{array}{l}0.018 \\
(0.05)\end{array}$ & & & & \\
\hline cons & & & & & $\begin{array}{c}1.098^{* *} \\
(0.46) \\
\end{array}$ & & \\
\hline $\mathrm{N}$ & 474 & 485 & 361 & 456 & 492 & 448 & 387 \\
\hline cent. $\mathrm{R}^{2}$ & 0.859 & 0.860 & 0.879 & 0.863 & & 0.866 & \\
\hline F-stat & 349 & 342 & 503 & 345 & & 602 & \\
\hline p-value Sargan & & & & & & & 0.024 \\
\hline p-value Hansen & & & & & & 0.108 & 0.041 \\
\hline $\mathrm{p}$-value $A R(1)$ & & & & & & & 0.200 \\
\hline$p$-value $A R(2)$ & 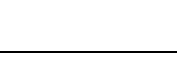 & & & & & & 0.481 \\
\hline
\end{tabular}


Table 3. Investment function, dependent variable: $\log \left(I_{t}\right)$

\begin{tabular}{|c|c|c|c|c|c|c|}
\hline & (1) & (2) & (3) & (4) & (5) & (6) \\
\hline & $\mathrm{FD}$ & FD & FD & MG & $\mathrm{A} \& \mathrm{H}$ & GMM \\
\hline $\log (I)_{t-1}$ & & & & & $\begin{array}{c}0.803 * * * \\
(0.05)\end{array}$ & $\begin{array}{c}1.083^{* * *} \\
(0.10)\end{array}$ \\
\hline $\log (Y)_{t}$ & $\begin{array}{c}1.910 * * * \\
(0.12)\end{array}$ & $\begin{array}{c}1.896 * * * \\
(0.10)\end{array}$ & $\begin{array}{c}2.169 * * * \\
(0.11)\end{array}$ & $\begin{array}{c}1.826 * * * \\
(0.26)\end{array}$ & $\begin{array}{c}2.155^{* * *} \\
(0.16)\end{array}$ & $\begin{array}{c}2.154 * * * \\
(0.19)\end{array}$ \\
\hline $\log (Y)_{t-1}$ & $\begin{array}{c}-0.558 * * * \\
(0.17)\end{array}$ & $\begin{array}{c}-0.490 * * * \\
(0.14)\end{array}$ & $\begin{array}{c}-0.602 * * * \\
(0.17)\end{array}$ & $\begin{array}{c}-0.832 * * * \\
(0.26)\end{array}$ & $\begin{array}{c}-1.845^{* * *} \\
(0.17)\end{array}$ & $\begin{array}{c}-2.400 * * * \\
(0.29)\end{array}$ \\
\hline $\log (W S)_{t}$ & $\begin{array}{c}0.501 * * * \\
(0.16)\end{array}$ & $\begin{array}{c}0.424^{* * *} \\
(0.14)\end{array}$ & $\begin{array}{c}0.745^{* * *} \\
(0.15)\end{array}$ & $\begin{array}{c}0.815^{* * *} \\
(0.21)\end{array}$ & $\begin{array}{l}0.186 \\
(0.26)\end{array}$ & $\begin{array}{r}-0.126 \\
(0.21)\end{array}$ \\
\hline $\log (W S)_{t-1}$ & $\begin{array}{c}-0.482 * * * \\
(0.11)\end{array}$ & $\begin{array}{c}-0.422^{* * *} \\
(0.10)\end{array}$ & $\begin{array}{c}-0.430 * * * \\
(0.12)\end{array}$ & $\begin{array}{c}-1.093^{* * *} \\
(0.28)\end{array}$ & $\begin{array}{c}-0.533^{* * *} \\
(0.12)\end{array}$ & $\begin{array}{c}-0.647^{* * *} \\
(0.15)\end{array}$ \\
\hline $\mathrm{i}_{\mathrm{t}}$ & $\begin{array}{c}-0.513^{* * *} \\
(0.13)\end{array}$ & $\begin{array}{c}-0.432 * * * \\
(0.12)\end{array}$ & $\begin{array}{c}-0.674 * * * \\
(0.13)\end{array}$ & $\begin{array}{c}-0.914 * * * \\
(0.24)\end{array}$ & $\begin{array}{c}-0.315^{* *} \\
(0.13)\end{array}$ & $\begin{array}{l}-0.239 \\
(0.16)\end{array}$ \\
\hline $\log (P P)_{t}$ & $\begin{array}{c}0.276^{* * *} \\
(0.02)\end{array}$ & $\begin{array}{c}0.264 * * * \\
(0.03)\end{array}$ & & $\begin{array}{c}0.221 * * * \\
(0.05)\end{array}$ & $\begin{array}{c}0.106 * * * \\
(0.03)\end{array}$ & $\begin{array}{l}0.037 \\
(0.06)\end{array}$ \\
\hline $\log (S P)_{t}$ & $\begin{array}{l}0.007 \\
(0.01)\end{array}$ & $\begin{array}{l}0.006 \\
(0.01)\end{array}$ & & $\begin{array}{c}0.045^{* *} \\
(0.02)\end{array}$ & $\begin{array}{r}-0.014 \\
(0.01)\end{array}$ & $\begin{array}{c}-0.020 * \\
(0.01)\end{array}$ \\
\hline $\log (D B)_{t}$ & $\begin{array}{l}-0.003 \\
(0.02)\end{array}$ & $\begin{array}{r}-0.001 \\
(0.02)\end{array}$ & $\begin{array}{r}-0.062 \\
(0.04)\end{array}$ & $\begin{array}{l}0.031 \\
(0.06)\end{array}$ & $\begin{array}{c}-0.065^{* *} \\
(0.03)\end{array}$ & $\begin{array}{c}-0.065^{*} \\
(0.03)\end{array}$ \\
\hline$\Delta \log (\mathrm{DB})_{\mathrm{t}}$ & & & $\begin{array}{l}0.045 \\
(0.04)\end{array}$ & & & \\
\hline $\log (\mathrm{DH})_{\mathrm{t}}$ & $\begin{array}{c}-0.105^{* * *} \\
(0.04)\end{array}$ & $\begin{array}{c}-0.106 * * * \\
(0.04)\end{array}$ & $\begin{array}{l}0.005 \\
(0.05)\end{array}$ & $\begin{array}{l}-0.085 \\
(0.11)\end{array}$ & $\begin{array}{l}-0.063 \\
(0.04)\end{array}$ & $\begin{array}{l}0.011 \\
(0.09)\end{array}$ \\
\hline$\Delta \log (\mathrm{DH})_{\mathrm{t}}$ & & & $\begin{array}{c}0.214^{* * *} \\
(0.07)\end{array}$ & & & \\
\hline $\log (\mathrm{TOP} 1)_{\mathrm{t}}$ & $\begin{array}{l}-0.002 \\
(0.02)\end{array}$ & & $\begin{array}{l}-0.006 \\
(0.02)\end{array}$ & $\begin{array}{r}-0.049 \\
(0.09)\end{array}$ & $\begin{array}{c}0.051 * * * \\
(0.01)\end{array}$ & $\begin{array}{c}0.063 * * * \\
(0.02)\end{array}$ \\
\hline $\log (\mathrm{GINI})_{\mathrm{t}}$ & & $\begin{array}{c}-0.191 * * * \\
(0.07)\end{array}$ & & & & \\
\hline cons & & & & $\begin{array}{c}-2.258^{*} \\
(1.19) \\
\end{array}$ & & \\
\hline $\mathrm{N}$ & 407 & 403 & 404 & 423 & 395 & 387 \\
\hline cent. $\mathrm{R}^{2}$ & 0.746 & 0.755 & 0.711 & & 0.728 & \\
\hline F-stat & 337 & 252 & 804 & & 1629 & 5927 \\
\hline $\mathrm{H}_{0}: \mathrm{WS}_{\mathrm{t}}+\mathrm{WS}_{\mathrm{t}-1}=0$ & 0.906 & 0.988 & 0.037 & 0.395 & 0.133 & 0.071 \\
\hline p-value Sargan & & & & & & 0.705 \\
\hline p-value Hansen & & & & & 0.014 & 0.611 \\
\hline$p$-value $A R(1)$ & & & & & & 0.004 \\
\hline$p$-value $A R(2)$ & 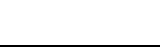 & 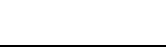 & & & 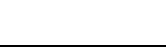 & 0.440 \\
\hline
\end{tabular}


Table 4. Foreign sector, dependent variables: $\log \left(X_{t}\right)$ and $\log \left(M_{t}\right)$

\begin{tabular}{|c|c|c|c|c|}
\hline & $\begin{array}{c}(1) \\
X: F D \\
\end{array}$ & $\begin{array}{c}(2) \\
X: A \& H \\
\end{array}$ & $\begin{array}{c}(3) \\
M: F D \\
\end{array}$ & $\begin{array}{c}(4) \\
M: A \& H \\
\end{array}$ \\
\hline lagged dep. var. & & $\begin{array}{l}0.249 \\
(0.25)\end{array}$ & & $\begin{array}{l}-0.170 \\
(0.21)\end{array}$ \\
\hline $\log \left(Y^{f}\right)_{t}$ & $\begin{array}{c}2.450 * * * \\
(0.18)\end{array}$ & $\begin{array}{c}2.585 * * * \\
(0.27)\end{array}$ & & \\
\hline $\log \left(Y^{f}\right)_{t-1}$ & $\begin{array}{c}-0.493 * * * \\
(0.18)\end{array}$ & $\begin{array}{c}-1.098 * \\
(0.65)\end{array}$ & & \\
\hline $\log (Y)_{t}$ & & & $\begin{array}{c}1.306 * * * \\
(0.19)\end{array}$ & $\begin{array}{c}1.419 * * * \\
(0.31)\end{array}$ \\
\hline $\log (W S)_{t}$ & & & $\begin{array}{c}0.09 \\
(0.09)\end{array}$ & $\begin{array}{l}0.176 \\
(0.13)\end{array}$ \\
\hline $\log (W S)_{t-1}$ & $\begin{array}{c}-0.247^{* *} \\
(0.11)\end{array}$ & $\begin{array}{l}-0.161 \\
(0.10)\end{array}$ & $\begin{array}{l}-0.087 \\
(0.06)\end{array}$ & $\begin{array}{c}-0.124 \\
(0.08)\end{array}$ \\
\hline $\log (E X)_{t}$ & $\begin{array}{c}-0.185^{* * *} \\
(0.02)\end{array}$ & $\begin{array}{c}-0.196 * * * \\
(0.03)\end{array}$ & $\begin{array}{c}0.159 * * \\
(0.06)\end{array}$ & $\begin{array}{c}0.142 * \\
(0.08)\end{array}$ \\
\hline $\log (E X)_{t-1}$ & $\begin{array}{c}-0.115^{* * *} \\
(0.04)\end{array}$ & $\begin{array}{r}-0.053 \\
(0.07)\end{array}$ & & \\
\hline $\log (P P)_{t}$ & $\begin{array}{c}-0.104 * * * \\
(0.03)\end{array}$ & $\begin{array}{c}-0.089 * * * \\
(0.03)\end{array}$ & $\begin{array}{c}0.186 * * * \\
(0.04)\end{array}$ & $\begin{array}{c}0.152 * * \\
(0.06)\end{array}$ \\
\hline $\log (P P)_{t-1}$ & & & $\begin{array}{c}-0.098 * * * \\
(0.03)\end{array}$ & \\
\hline $\log (X)_{t}$ & & & $\begin{array}{c}0.443 * * * \\
(0.05)\end{array}$ & $\begin{array}{c}0.421 * * * \\
(0.08)\end{array}$ \\
\hline $\log (X)_{t-1}$ & & & $\begin{array}{c}-0.091^{* *} \\
(0.04)\end{array}$ & $\begin{array}{l}0.016 \\
(0.15) \\
\end{array}$ \\
\hline $\mathrm{N}$ & 481 & 468 & 496 & 483 \\
\hline cent. $\mathrm{R}^{2}$ & 0.728 & 0.547 & 0.806 & 0.791 \\
\hline F-stat & 198 & 373 & 265 & 328 \\
\hline p-value Hansen & & 0.940 & & 0.031 \\
\hline
\end{tabular}

$* \mathrm{p}<0.1, * * \mathrm{p}<0.05, * * * \mathrm{p}<0.01$, heteroskedastic and autocorrelation robust standard errors reported in brackets. 
Table 5. Marginal effect of 1 percentage point shift of WS in \% of GDP on private excess demand

\begin{tabular}{ccccccc} 
& PANEL & US & FR & DE & AT & NL \\
\hline \hline $\mathrm{C}$ & 0.12 & 0.14 & 0.11 & 0.12 & 0.11 & 0.10 \\
$\mathrm{I}$ & 0.01 & 0.01 & 0.01 & 0.01 & 0.01 & 0.01 \\
$\mathrm{NX}$ & -0.05 & -0.02 & -0.06 & -0.08 & -0.10 & -0.15 \\
\hline $\mathrm{Y}^{\mathrm{PED}}$ & 0.08 & 0.12 & 0.06 & 0.04 & 0.02 & -0.05 \\
openness & $21 \%$ & $11 \%$ & $24 \%$ & $33 \%$ & $42 \%$ & $61 \%$ \\
\hline
\end{tabular}

Effects are based on coefficients from specification (1) in Table 1 and Table 2 and specifications (1) and (3) in Table 3. Elasticities are converted into marginal effects using GDP weighted sample averages. Openness is computed as the average of nominal import and export shares: $\left(P_{M} M+P_{X} X\right) / 2 P_{Y} Y$.

Table 6. Growth contributions

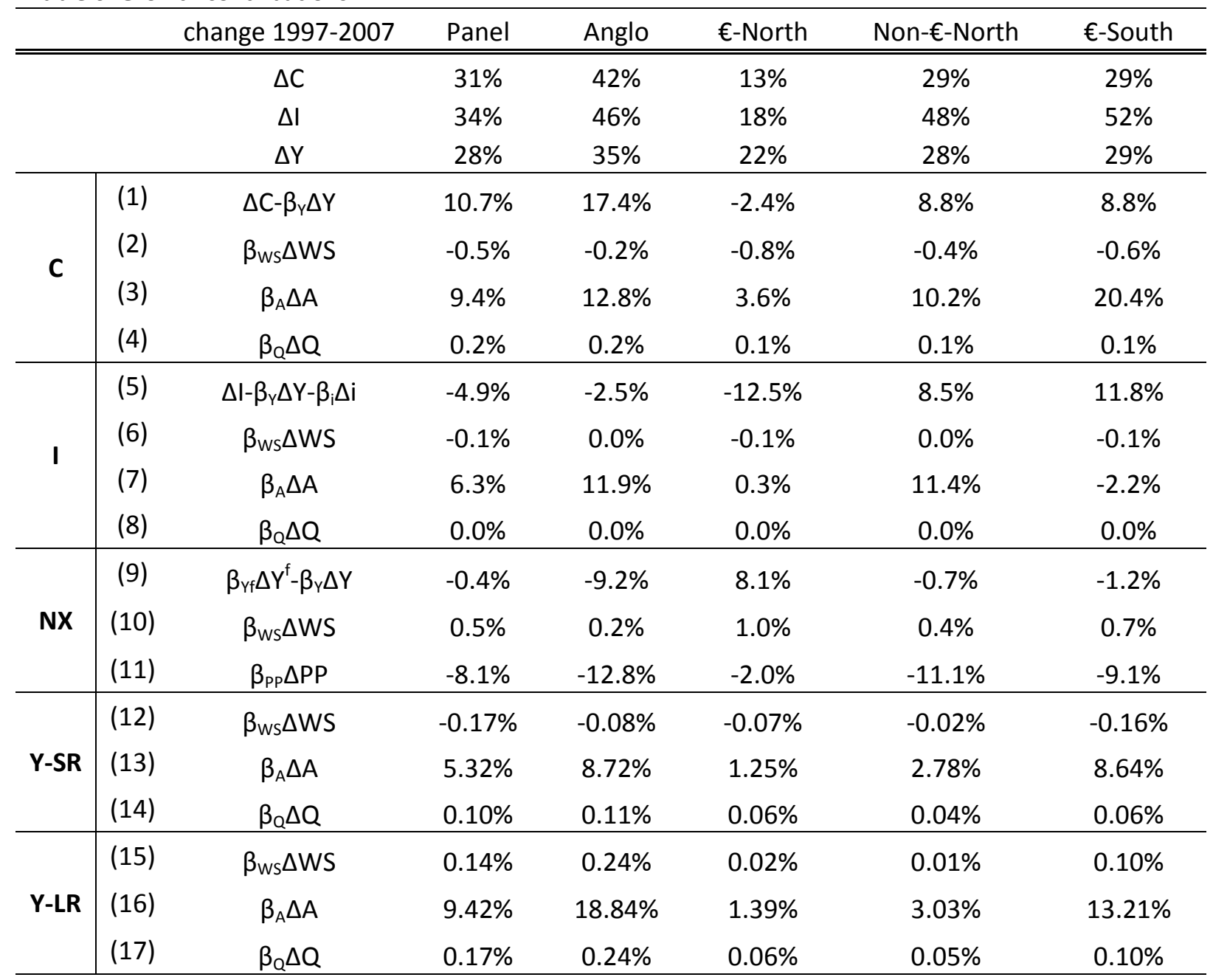

Rows (1) and (5) report the change of $C$ and $I$ between 1997 and 2007 not explained by changes in income (and the interest rate), respectively. Rows (2), (6) and (10) report the predicted change in $C, I$ and $N X$, based on the change in $W S$ and the estimates from specifications (1) in Tables 2, 3 and 4. Rows (3) and (7) report the predicted change in $C$ and $I$ based on the changes and the corresponding coefficients of property and stock prices as well as household debt: $\beta_{A} \Delta A=\beta_{P P} \Delta P P+\beta_{S P} \Delta S P+\beta_{D H} \Delta D H$. Rows (4) and (8) report the predicted change in $C$ and $I$ based on the change in Top 1\% income share changes. Row (9) contain the predicted change in $N X$ due to the changes in $Y$ and $Y^{f}$. Row (11) reports similar results but due to changes in $P P$. Rows (12) to (14) report short run total GDP effects based on $f_{2}$ of equation (5) and rows (15) to (17) report the long run equivalents taking also into account the multiplier effect of $f_{1}$ from equation (5). 


\section{Appendix}

Table A1. Data definitions and sources

\begin{tabular}{|c|c|c|c|}
\hline abbreviation & full variable name & unit & source \\
\hline WS & $\begin{array}{l}\text { Adjusted wage share: total economy: as } \\
\text { percentage of GDP at current factor cost } \\
\text { (ALCD2) }\end{array}$ & $\%$ GDP & AMECO \\
\hline $\mathrm{Y}$ & $\begin{array}{l}\text { Gross domestic product at } 2005 \text { market } \\
\text { prices (OVGD) }\end{array}$ & $\begin{array}{l}\text { Billion, national } \\
\text { currency }\end{array}$ & AMECO \\
\hline PY & $\begin{array}{l}\text { Price deflator gross domestic product at } \\
\text { market prices (PVGD) }\end{array}$ & $2005=1$ & AMECO \\
\hline C & $\begin{array}{l}\text { Private final consumption expenditure at } \\
2005 \text { prices }(\mathrm{OCPH})\end{array}$ & $\begin{array}{l}\text { Billion, national } \\
\text { currency }\end{array}$ & AMECO \\
\hline PC & $\begin{array}{l}\text { Price deflator private final consumption } \\
\text { expenditure (PCPH) }\end{array}$ & $2005=1$ & AMECO \\
\hline 1 & $\begin{array}{l}\text { Gross fixed capital formation at } 2005 \\
\text { prices: total economy (OIGT) }\end{array}$ & $\begin{array}{l}\text { Billion, national } \\
\text { currency }\end{array}$ & AMECO \\
\hline $\mathrm{PI}$ & $\begin{array}{l}\text { Price deflator gross fixed capital formation: } \\
\text { total economy (PIGT) }\end{array}$ & $2005=1$ & AMECO \\
\hline PM & $\begin{array}{l}\text { Price deflator imports of goods and } \\
\text { services (PMGS) }\end{array}$ & $2005=1$ & AMECO \\
\hline M & $\begin{array}{l}\text { Imports of goods and services at } 2005 \\
\text { prices (OMGS) }\end{array}$ & $\begin{array}{l}\text { Billion, national } \\
\text { currency }\end{array}$ & AMECO \\
\hline$x$ & $\begin{array}{l}\text { Exports of goods and services at } 2005 \\
\text { prices (OXGS) }\end{array}$ & $\begin{array}{l}\text { Billion, national } \\
\text { currency }\end{array}$ & AMECO \\
\hline PX & $\begin{array}{l}\text { Price deflator exports of goods and } \\
\text { services (PXGS) }\end{array}$ & $2005=1$ & AMECO \\
\hline $\mathrm{i}$ & Real long-term interest rates, deflator GDP & $\%$ & $\begin{array}{l}\text { AMECO and OECD } \\
\text { (MEI) }\end{array}$ \\
\hline $\mathrm{DH}$ & Household and NPISH, all liabilities & $\begin{array}{l}\text { Billion, national } \\
\text { currency }\end{array}$ & BIS \\
\hline DB & $\begin{array}{l}\text { Non-financial corporate, all liabilities less } \\
\text { shares and other equity }\end{array}$ & $\%$ GDP & BIS \\
\hline PP & $\begin{array}{l}\text { real property prices BIS (exact definitions } \\
\text { vary, deflated with CPI) }\end{array}$ & $2005=1$ & BIS and OECD \\
\hline SP & share price index; CPI deflated & $2005=1$ & $\begin{array}{l}\text { IMF (International } \\
\text { Financial Statistics) } \\
\text { and OECD (MEI) }\end{array}$ \\
\hline EHII & estimated Gini index & Gini Index & $\begin{array}{l}\text { University of Texas } \\
\text { Inequality Project }\end{array}$ \\
\hline$Y^{f}$ & OECD real GDP & $2005=1$ & OECD \\
\hline IC & $\begin{array}{l}\text { Gross fixed capital formation at } 2005 \\
\text { prices: construction (OIGCO) }\end{array}$ & $\begin{array}{l}\text { Billion, national } \\
\text { currency }\end{array}$ & AMECO \\
\hline GINI & $\begin{array}{l}\text { gini coefficient (pre tax and post transfer) } \\
\text { of the Standardized World Income } \\
\text { Inequality Database }\end{array}$ & Gini Index & SWIID \\
\hline TOP1 & top $1 \%$ income share of the SWIID & $\%$ of income & SWIID \\
\hline EX & Nominal effective exchange rate & $2005=1$ & BIS \\
\hline
\end{tabular}


Table A2. Descriptive Statistics

\begin{tabular}{c|ccccc|c}
\hline variable & $\mathrm{N}$ & Mean & std. dev. & min & max & unit \\
\hline \hline C & 596 & 15,275 & 59,570 & 27 & 314,756 & Billion, national currency \\
Y & 596 & 26,279 & 102,586 & 44 & 530,027 & Billion, national currency \\
I & 596 & 6,374 & 25,097 & 12 & 129,739 & Billion, national currency \\
M & 596 & 2,967 & 11,502 & 14 & 74,847 & Billion, national currency \\
X & 596 & 3,168 & 12,556 & 11 & 87,405 & Billion, national currency \\
DH & 527 & 20,000 & 74,519 & 20 & 356,783 & Billion, national currency \\
PX & 596 & 0.93 & 0.19 & 0.32 & 1.72 & $2005=1$ \\
PM & 596 & 0.95 & 0.16 & 0.38 & 1.76 & $2005=1$ \\
PI & 596 & 0.87 & 0.20 & 0.24 & 1.35 & $2005=1$ \\
PC & 596 & 0.84 & 0.21 & 0.23 & 1.26 & $2005=1$ \\
PY & 596 & 0.84 & 0.22 & 0.22 & 1.39 & $2005=1$ \\
Top1 & 561 & 0.081 & 0.028 & 0.035 & 0.183 & $\%$ of income \\
GINI & 579 & 0.448 & 0.047 & 0.285 & 0.564 & Gini between 0 and 1 \\
EHII & 449 & 0.355 & 0.029 & 0.276 & 0.432 & Gini between 0 and 1 \\
WS & 596 & 0.67 & 0.05 & 0.49 & 0.77 & $\%$ of GDP \\
DB & 480 & 1.06 & 0.38 & 0.29 & 2.17 & \% of GDP \\
PP & 585 & 0.79 & 0.28 & 0.27 & 1.61 & $2005=1$ \\
Y & 580 & 0.80 & 0.19 & 0.50 & 1.08 & $2005=1$ \\
EX & 596 & 1.02 & 0.15 & 0.45 & 1.79 & $2005=1$ \\
SP & 592 & 0.69 & 0.37 & 0.07 & 2.19 & $2005=1$ \\
i & 574 & 0.04 & 0.03 & -0.08 & 0.14 & $\%$ \\
& & & & & &
\end{tabular}


Table A3. Unit root tests following Choi (2001)

\begin{tabular}{|c|c|c|c|c|c|}
\hline variable & inv. chi-squared & inverse logit & inverse normal & specification & transformation \\
\hline $\mathrm{C}$ & 0.511 & 0.756 & 0.768 & trend & log-level \\
\hline$Y$ & 0.989 & 1.000 & 1.000 & trend & log-level \\
\hline PP & 0.156 & 0.408 & 0.455 & trend & log-level \\
\hline $\mathrm{SP}$ & 0.043 & 0.108 & 0.094 & trend & log-level \\
\hline $\mathrm{DHH}$ & 0.217 & 0.411 & 0.392 & trend & log-level \\
\hline TOP1 & 0.237 & 0.467 & 0.498 & trend & log-level \\
\hline DBUS & 0.362 & 0.303 & 0.272 & trend & log-level \\
\hline inv & 0.152 & 0.472 & 0.578 & trend & log-level \\
\hline$x$ & 0.991 & 1.000 & 1.000 & trend & log-level \\
\hline$M$ & 0.784 & 0.989 & 0.983 & trend & log-level \\
\hline WSfc & 0.235 & 0.456 & 0.494 & no trend & log-level \\
\hline $\mathrm{i}$ & 0.723 & 0.559 & 0.560 & no trend & level \\
\hline exnom & 0.063 & 0.027 & 0.022 & no trend & log-level \\
\hline $\mathrm{C}$ & 0.010 & 0.005 & 0.003 & no trend & log-dif \\
\hline Y (2 lags) & 0.019 & 0.034 & 0.055 & no trend & log-dif \\
\hline PP & 0.000 & 0.000 & 0.000 & no trend & log-dif \\
\hline $\mathrm{SP}$ & 0.000 & 0.000 & 0.000 & no trend & log-dif \\
\hline $\mathrm{DHH}$ & 0.062 & 0.026 & 0.021 & no trend & log-dif \\
\hline Top1 & 0.000 & 0.000 & 0.000 & no trend & log-dif \\
\hline DBUS & 0.001 & 0.000 & 0.000 & no trend & log-dif \\
\hline inv & 0.001 & 0.001 & 0.000 & no trend & log-dif \\
\hline X (2 lags) & 0.071 & 0.054 & 0.047 & no trend & log-dif \\
\hline$M$ & 0.000 & 0.000 & 0.000 & no trend & log-dif \\
\hline WSfc & 0.000 & 0.000 & 0.000 & no trend & log-dif \\
\hline $\mathrm{i}$ & 0.000 & 0.000 & 0.000 & no trend & dif \\
\hline exnoml & 0.000 & 0.000 & 0.000 & no trend & log-dif \\
\hline
\end{tabular}

